\title{
KEGUNAAN GINKGO BILOBA UNTUK PENGOBATAN PENYAKIT NEUROLOGIS
}

\author{
Muftia Jauristika sarifuddin ${ }^{1}$, Nurul Annisa ${ }^{1}$ \\ Program Studi Pendidikan Dokter, Fakultas Kedokteran dan Ilmu Kesehatan, Universitas Islam Negeri Alauddin
}

\begin{abstract}
Ginkgo Biloba is a plant that is classified as a phytopharmaca or medicine derived from plants, namely Ginkgo biloba G.biloba plant $(G b)$ is included in the Ginkgoceae family. In G.biloba extract, there are antioxidants, antiviral, anti-inflammatory, and anti-carcinogenic. And it has also been stated that G.biloba extract has a good effect on CNS (central nervous system) function. To find out the benefits of G.biloba in the treatment of neurological disorders. Created by using the literature study method to collect valid references regarding the Ginkgo Biloba plant which can be used as a treatment for neurological disorders. The results of the literature review based on the literature study conducted show that the Ginkgo Biloba plant can be used as a treatment for neurological diseases with its contents and effects on the body. In this literature review, it was found that Ginkgo Biloba can be used as a treatment for neurological disorders
\end{abstract}

Keywords: Ginkgo Biloba, Central Nervous System, Neurological

\begin{abstract}
Abstrak
Ginkgo Biloba adalah Salah satu tanaman yang tergolong sebagai fitofarmaka atau obat-obatan yang berasal dari tanaman ialah Ginkgo biloba Tanaman G.biloba $(\mathrm{Gb})$ termasuk dalam familia Ginkgoceae. Di dalam ekstrak G.biloba terdapat antioksidan, antivirus, antiinflamasi, dan juga antikarsinogenik. Dan juga telah dinyatakan bahwa ekstrak G.biloba mempunyai efek yang baik terhadap fungsi SSP (sistem saraf pusat). Untuk mengetahui manfaat G.biloba dalam penanganan gangguan neurologis. Dibuat dengan menggunakan metode studi pustaka untuk mengumpulkan referensi yang valid mengenai tanaman Ginkgo Biloba yang dapat digunakan sebagai penanganan gangguan Neurologi. Hasil literature review berdasarkan studi pustaka yang dilakukan menunujukkan bahwa tanaman Ginkgo Biloba yang dapat digunakan sebagai penanganan penyakit neuorologis dengan kandungan dan efek terhadap tubuh. Dalam literature review ini didapatkan tanaman Ginkgo Biloba yang dapat digunakan sebagai penanganan gangguan neurologis
\end{abstract}

Kata Kunci: Ginkgo Biloba, Sistem Saraf Pusat, Neurologis.

\section{PENDAHULUAN}

Berdasarkan dari penelitian yang telah dilakukan oleh Global Burden of Disease diketahui bahwa salah satu masalah kesehatan masyarakat terbesar ialah gangguan neurologis. Hal ini terjadi di beberapa negara mulai dari negara yang berkembang sampai negara maju, bahkan tidak ada kebijakan dalam upaya penanganannya. Karena itu, dibutuhkan upaya yang cepat dan tepat dalam penanganan gangguan neurologis, dan juga upaya pencegahan yang baik sehingga bisa menurunkan prevalensi gangguan neurologis di masyarakat. Dalam hal itu, selain dengan pengobatan dengan obatobatan, bisa juga dilakukan dengan mengkonsumsi beberapa tanaman-tanaman herbal. Salah satu tanaman yang tergolong sebagai fitofarmaka atau obat-obatan yang berasal dari tanaman ialah Ginkgo biloba. 
Pada beberapa penelitian, G. biloba diketahui bisa memberikan efek yang menguntungkan pada beberapa penyakit neurologis.

Tanaman G.biloba (Gb) termasuk dalam familia Ginkgoceae yang banyak tumbuh secara liar di China dan dipakai untuk pengobatan tradisional sejak tahun lalu. Sekitar 5000 tahun lalu tanaman G.biloba ini digunakan di China sebagai obat jantung dan paru-paru seperti penyakit asma dan bronchitis. Tanaman ini pertama kali dibawa ke Eropa pada tahun 1700 dan dalam dua dekade terakhir ini efektivitas tanaman ini banyak diteliti di Amerika dan Eropa dalam hal pengobatan. Sampai saat ini tanaman G.biloba tersedia dalam bentuk pil yang sering diresepkan di Jerman dan Perancis. Penjualan ekstrak G.biloba mencapai 50\% dari kelompok obat-obatan yang berasal dari tanaman (fitofarmaka). Hal ini mungkin disebabkan karena reputasi baik mengenai kemanjuran dari obat ini serta adanya simpati masyarakat terhadap obat-obatan fitofarmaka, disamping itu juga karena harganya yang relatif murah.

\section{METODE}

Literatur review ini dibuat dengan menggunakan metode studi pustaka untuk mengumpulkan referensi yang valid mengenai tanaman herbal yaitu G,biloba dan kegunaannya dalam penanganan gangguan neurologis. Pengumpulan beberapa referensi dari internet dengan sumber terpercaya seperti PubMed.

\section{PEMBAHASAN}

Tanaman Ginkgo biloba biasa juga disebut dengan pohon maidenhair, disebut "fosil hidup" karena spesies tersebut

merupakan satu-satunya anggota family Ginkgoaceae yang masih ada. Tanaman ini sudah digunakan sebagai obat herbal semenjak akhir abad ke-15 di Cina. Ekstrak G.biloba diketahui mengandung sekitar 300 zat kimia, akan tetapi belum diketahui secara jelas fungsi dari masingmasing zat kimia tersebut. Di dalam ekstrak G.biloba terdapat antioksidan, antivirus, antiinflamasi, dan juga antikarsinogenik. Dan juga telah dinyatakan bahwa ekstrak G.biloba mempunyai efek yang baik terhadap fungsi SSP (sistem saraf pusat). ${ }^{1}$

Terdapat 2 zat yang paling aktif didalam ekstrak Egb761, yaitu terpenoid dan flavonoid. Formulasi standar mengandung $24 \%$ glikosida flavonoid (Terutama dihidrolisis menjadi aglikon flavon seperti quercetin, kaempferol, dan isorhamnetin) dan $6 \%$ terpene lakton (2,8\% 3,4\% ginkgolides A, B, dan C, dan 2,6\% 3,2\% bilobalida). ${ }^{30}$ Flavonoid adalah senyawa polifenol herbal dengan berat molekul rendah yang membentuk keluarga besar, memberikan efek antioksidan dengan menetralkan radikal peroksil, Perhidroksil, dan hidroksil. Asam ginkgolat, senyawa fenolik toksik di EGb761, memiliki waktu paruh plasma 45 jam dan tersirat dalam efek alergi dan imunotoksik. Oleh karena itu, disarankan agar kadar asam ginkgolat tidak melebihi 5 $\mu \mathrm{g} / \mathrm{g}$ dalam sediaan oleh Institut Federal Jerman untuk Obat dan Alat Kesehatan Komisi. Pada manusia, disarankan agar ekstrak GB standar digunakan pada dosis $240 \mathrm{mg} /$ hari aman dan tidak memiliki 
interaksi dengan nonphytomedications

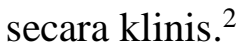

\section{冈}

Gambar 1. Efek farmakologi dalam ekstrak G.biloba ${ }^{1}$

Di dalam kandungan ekstrak G.biloba terdapat antioksidan yang kuat dalam melindungi sel endotel vascular dari stress oxidative dengan cara menghilangkan radikal bebas. Tak hanya itu, meningkatkan aliran darah otak dan perifer melalui modulasi aliran darah, menurunkan permeabilitas vaskular, mengaktivasi langsung sistem saraf melalui neuron, dan juga menurunkan agregasi trombosit melalui blokade reaksi biokimia dalam trombosit dapat dilakukan oleh G.biloba dalam meningkatkan efek neuroprotektif. Diketahui pula bahwa terdapat efek antiinflamasi pada ekstrak G.biloba yang berhubungan dengan penghambatan siklooksigenase (COX) dan lipoksigenase yang diperankan oleh zat flavonoid di dalamnya. Ginkgetin (biflavon dari daun G.biloba) menghambat fosfolipase-A2, menghidrolisis gliserofosfolipid membrane dan fase prostaglandin D yang bergantung pada COX2 untuk melepaskan asam arakidonat (precursor untuk eicosanoid), prostaglandin, dan leukotrien. Selain itu, ginkgolide A dan B (flavonoid G.biloba) menghambat sitokin proinflamasi seperti TNF- $\alpha$ dan IL-1. Faktor aktivasi trombosit (PAF) merangsang sintesis leukotriene yang terlibat dalam pathogenesis proses inflamasi. Ginkgolide B merupakan antagonis reseptor PAF kuat yang dianggap memiliki efek pelindung saraf (neuroprotektif) di SSP (sistem saraf pusat). Diketahui juga bahwa G.biloba mengaktifkan jalur sinyal yang terhubung dengan eritroid 2 faktor 2 (Nrf2), yang dikenal sebagai mekanisme molekuler utama dalam perlindungan terhadap stress oxidative dan penghapusan ekspresi gennya menghambat regenerasi neuron dengan merangsan gen fase II melalui Kelch-like ECH associated protein-1. 
$x$

Gambar 2. Mekanisme molecular efek pada ekstrak G.biloba ${ }^{1}$

Di dalam tubuh kita, sel-sel saraf diketahui apabila telah rusak ataupun mengalami proses degenerasi sudah pasti tidak bisa kembali menjadi sel saraf yang baik. Namun, telah ditemukan bahwa hilangnya fungsi saraf yang diakibatkan oleh gangguan neurologis ternyata bisa diperbaiki bahkan disembuhkan dengan regenerasi saraf, dimana hal ini berkaitan dengan neuron dan sel glial. ${ }^{2}$ Berdasarkan pengaplikasian di klinis dimana Neural Stem Cells (NSCs) telah dibatasi dalam jumlah terbatas. Akan tetapi, diferensiasi dari sel-sel batang eksogen yang berasal dari jaringan lain yang sukses bisa menjadi sel-sel saraf yang bisa menyediakan NSCs yang baru. ${ }^{3}$ Ekstrak EGb 761 memberikan efek pada NSCs melalui efek yang spesifik dengan Ginkgolide B pada NSCs. Terdapat beberapa penelitian dimana mereka mencaritahu hubungan antara dosis Ginkgolide B dan diferensiasi NSCs. Hasil penelitian juga didapatkan bahwa ekstrak
EGb761 bisa melawan radikal bebas, meningkatkan neurogenesis dan plastisitas sinaptik, menstabilkan membran sel, meningkatkan faktor neurotropik yang berasal dari otak, dan juga beradaptasi dengan lingkungan yang dibutuhkan selama proses diferensiasi sel punca menjadi sel-sel saraf. ${ }^{4}$

Hal ini juga berlaku untuk beberapa gejala neurosensorik seperti tinnitus dan vertigo yang biasanya dialami oleh penderita demensia. Pada sebuah penelitian case-control pada lansia yang memiliki gangguan neurologis, dimana mereka yang mengalami demensia memiliki tingkat jatuh sebesar $60 \%$, dimana mungkin terindikasi karena gangguan control keseimbangan dan prevalensi pusing yang lebih tinggi. ${ }^{5}$

Penelitian yang dilakukan di Jerman, didapatkan bahwa ekstrak Ginkgo biloba Egb 761 bisa meringankan gejala tinnitus dan juga vertigo atau pusing pada pasien 
demensia. ${ }^{6,7}$ Dalam mempertimbangkan mengapa ekstrak G.biloba EGb761 bisa meringankan tinnitus, pusing, atau vertigo pada pasien demensia, kita harus memperhatikan patomekanisme yang mendasari. Neuron dari sistem vestibular dan sistem pendengaran, sel-sel rambut koklea, dan sel-sel sensorik vestibular memiliki energy yang tinggi untuk mempertahankan dan terus menerus memperbaiki potensi listrik transmembran mereka. Adanya gangguan fungsi mitokondria dan gangguan perfungsi diduga berhubungan dengan disfungsi pada koklea dan vestibular, serta degenerasi sel sensorik. ${ }^{8}$ Ekstrak EGb 761 diketahui meningkatkan aliran darah pada telinga dalam dan otak dengan cara mengurangi viskositas darah. Hal itu juga bisa meningkatkan fungsi mitokondria dan metabolism energy, yang semuanya berhubungan dengan meningkatnya fungsi telinga bagian dalam dan otak pada orang tua dengan demensia yang sering memiliki kelianan pembuluh darah dan gangguan fungsi mitokondria. ${ }^{9-11}$ Sifat antiapoptopik dan neuroprotektif dari ekstrak EGb 761 bisa menghambat proses degenerasi seperti hilangnya sel sensori koklea dan vestibular, yang bisa berhubungan dengan tinnitus dan vertigo. ${ }^{12-17}$ Selain itu, ekstrak EGb 761 juga memiliki efek ansiolitik, dimana dengan melemahkan aktivasi sumbu tegangan bisa mengurangi tekanan seperti pada saat tinnitus. $9,18,19$

Hasil penelitian yang dilakukan oleh R. Spiegel et all pada tahun 2018 di Jerman, memberikan kesimpulan bahwa penggunaan ekstrak G.biloba EGb 761 jelas lebih unggul dibandingkan penggunaan obat placebo dalam penanganan tinnitus dan vertigo. Dan ekstrak EGb 761 pada dosis harian sebanyak $240 \quad \mathrm{mg}$ diketahui bisa meringankan tinnitus dan vertigo pada pasien demensia, yakni pada pasien yang sangat rentan mengalami gangguan tersebut. Selain itu, hal ini juga harus dipertimbangkan dalam memilih penanganan yang tepat untuk pasien penderita demensia dan pasien yang memiliki gejala gangguan neurosensori. ${ }^{20}$

Tidak hanya digunakan pada penderita demensia, ekstrak G.biloba juga bisa digunakan pada penderita Vascular Cognitif Impairment (VCI) atau gangguan kognitif vascular. VCI merupakan spketrum luas dari sindrom mulai dari gangguan kognitif ringan hingga demensia, yang dipengaruhi oleh faktor resiko penyakit serebrovaskular. Proses degenerasi pada serebrovaskular bisa menyebabkan kehilangan integritas sawar darah otak yang akan menyebabkan penurunan kognitif dan sensori-motorik. ${ }^{21}$

Pada penelitian yang dilakukan oleh Weinmann et al dengan metode metaanalisis menunjukkan bahwa ekstrak G.biloba lebih efektif dibandingkan penggunaan placebo pada penanganan pasien demensia. ${ }^{22}$ Hal ini didukung pula oleh penelitian yang dilakukan oleh Amieva et al bahwa penggunaan ekstrak G.biloba yang dikonsumsi secara teratur bisa memperlambat penurunan kognitif dibandingkan dengan piracetam. ${ }^{23}$ Selain itu, sebuat hasil studi yang dilaporkan oleh Brondino et al menyatakan bahwa pasien demensia yang diberikan pengobatan G.biloba mengalami peningkatan fungsi kognitif dan juga aktivitas hariannya. ${ }^{24} \mathrm{Hal}$ ini juga didukung oleh tinjauan sistematis dan penelitian dengan metode metaanalisis yang dilakukan oleh Yang et al, dimana mereka menemukan bahwa ekstrak G.biloba memiliki potensi untuk 
digunakan dalam meningkatkan fungsi kognitif, aktivitas kehidupan sehari-hari, dan penilaian klinis pada pasien yang mengalami gangguan kognitif ringan atau penderita Alzheimer. ${ }^{25}$ Sebuah review sistematis dari Cochrane Collaboration menyatakan bahwa uji coba secara acak dalam skala yang besar juga berkualitasi tinggi dibutuhkan untuk memperjelas efek yang positif dari G.biloba untuk pemulihan pada pasien stroke akut. ${ }^{26}$ Penelitian terbaru juga telah memberi bukti bahwa G.biloba memiliki manfaat dan aman digunakan dalam pengobatan infark serebral akut karena bisa meningkatkan hasil positif dan memberikan efek neuroprotektif. ${ }^{27,28}$ Akan tetapi, pada penelitian yang sebelumnya tidak ditemukan bukti bahwa G.biloba yang digunakan dalam penatalaksanaan profilaksis untuk stroke iskemik bisa mencegah terjadinya stroke ataupun kejadian kardiovaskular dan serebrovaskular lainnya. ${ }^{29}$ Walaupun begitu, bukti klinis untuk penggunaan G.biloba untuk memperlambat perkembangannya menjanjikan dan memerlukan penelitian-penelitian lebih lanjut.

\section{KESIMPULAN}

Salah satu tanaman yang tergolong sebagai fitofarmaka atau obat-obatan yang berasal dari tanaman ialah Ginkgo biloba. Biji ginkgo biloba juga dilaporkan mengandung anti-oksidan yang mampu meningkatkan fungsi sistem syaraf dan selsel otak, selain menurunkan viskositas darah dan melancarkan aliran darah khususnya pada sistem syaraf dan sel-sel otak. Tidak hanya digunakan pada penderita demensia, ekstrak G.biloba juga bisa digunakan pada penderita Vascular Cognitif Impairment (VCI) atau gangguan kognitif vascular.

\section{DAFTAR PUSTAKA}

1. Gunay NE. Ginkgo biloba extract as an antioxidant in nerveregeneration. Elsevier 2020.

2. Margitta Dziwenka, Robert W. Coppock pp. Nutraceuticals Efficacy, Safety and Toxicity. Chapter $49-$ Ginkgo biloba 681_691. Academic Press, San Diego, CA,USA; 2016.

3. Wang L, Zhang T, Bai K. [System evaluation on Ginkgo biloba extract in the treatment of acute cerebral infarction]. Zhong Nan Da Xue Xue Bao Yi Xue Ban. 2015;40(10):10961102. Chinese.

4. Chao R, Yin P, Ren N, Zhe W, Wang J, Zhang C, Wei G, Geng D, Wang X (2018) Cerebrospinal fluid-stem cell interactions may pave the path for cell-based therapy in neurological diseases. Stem Cell Res Ther 9:66-76.

5. Zhang DL, Li D, Wang MJ (2018) Mechanism and application of stem cell transplantation in the treatment of ischemic stroke. Zhongguo Zuzhi Gongcheng Yanjiu 22:5393-5398

6. Homann B, Plaschg A, Grundner M, et al. The impact of neurological disorders on the risk for falls in the community dwelling elderly: a c asecontrolled study. BMJ Open. 2013;3:e003367.

7. von Boetticher A. Ginkgo biloba extract in the treatment of tinnitus: a systematic review. Neuropsychiatr Dis Treat. 2011;7:441-447.

8. Hamann KF. Ginkgo-Spezialextrakt bei Schwindel. Ein systematischer 
Review randomisierter, doppelblinder, placebokontrollierter klinischer Prüfungen [Special Ginkgo extract in cases of vertigo: a systematic review of randomised, double-blind, placebocontrolled clinical examination]. HNO. 2007;55:258-263. German.

9. Yamasoba T, Lin FR, Someya S, Kashio A, Sakamoto T, Kondo K. Current concepts in age-related hearing loss: epidemiology and mechanistic pathways. Hear Res. 2013;303:30-38.

10. Lang F, Hoerr R, Noeldner M, Koch E. Ginkgo biloba extract EGb 761®: from an ancient Asian plant to a modern European herbal medicinal product. In: Wagner $\mathrm{H}$, UlrichMerzenich G, editors. Evidence and Rational Based Research on Chinese Drugs. Wien: Springer; 2013:431470.

11. Toledo JB, Arnold SE, Raible K, et al. Contribution of cerebrovascular disease in autopsy confirmed neurodegenerative disease cases in the National Alzheimer's Coordinating Centre. Brain. 2013;136:2697-2706.

12. Eckert A, Keil U, Scherping I, Hauptmann S, Müller WE. Stabilization of mitochondrial membrane potential and improvement of neuronal energy metabolism by Ginkgo biloba extract EGb 761. Ann N Y Acad Sci. 2005;1056:474-485.

13. Luo Y, Smith JV, Paramasivam V, et al. Inhibition of amyloid- $\beta$ aggregation and caspase- 3 activation by the Ginkgo biloba extract EGb 761. Proc Natl Acad Sci U S A. 2002;99:12197-12202.

14. Massieu L, Morán J, Christen Y. Effect of Ginkgo biloba (EGb 761) on staurosporine-induced neuronal death and caspase activity in cortical cultured neurons. Brain Res. 2004;1002:76-85.

15. Schindowski K, Leutner $S$, Kressmann S, Eckert A, Müller WE. Age-related increase of oxidative stress-induced apoptosis in mice. Prevention by Ginkgo biloba extract (EGb 761). J Neural Transm. 2001;108:969-978.

16. Yang $\mathrm{TH}$, Young YH, Liu SH. EGb 761 (Ginkgo biloba) protects cochlear hair cells against ototoxicity induced by gentamicin via reducing reactive oxygen species and nitric oxiderelated apoptosis. J Nutr Biochem. 2011;22:886-894.

17. Makary CA, Shin J, Kujawa SG, Liberman MC, Merchant SN. Agerelated primary cochlear neuronal degeneration in human temporal bones. J Assoc Res Otolaryngol. 2011;12:711-717.

18. Walther LE, Westhofen M. Presbyvertigo - aging of otoconia and vestibular sensory cells. J Vestib Res. 2007;17:89-92.

19. Woelk H, Arnoldt KH, Kieser M, Hoerr R. Ginkgo biloba special extract EGb $761{ }^{\circledR}$ in generalized anxiety disorder and adjustment disorder with anxious mood: a randomized, doubleblind, placebo-controlled trial. $\mathrm{J}$ Psychiatr Res. 2007;41:472-480.

20. Jezova D, Duncko R, Lassanova M, Kriska M, Moncek F. Reduction of rise in blood pressure and cortisol release during stress by Ginkgo biloba extract (EGb

21. Rainer S, et all. Ginkgo biloba extract $\mathrm{EGb} 761^{\circledR}$ alleviates neurosensory symptoms in patients with dementia: a 
meta-analysis of treatment effects on tinnitus and dizziness in randomized, placebo-controlled trials. Dovepress. 2018

22. Battistin L, Cagnin A. Vascular cognitive disorder. A biological and clinical overview. Neurochem Res. 2010;35(12):1933-1938.

23. Weinmann S, Roll S, Schwarzbach C, Vauth C, Willich SN. Effects of Ginkgo biloba in dementia: systematic review and meta-analysis. BMC Geriatr. 2010;10:14.

24. Amieva $\mathrm{H}$, Meillon $\mathrm{C}$, Helmer $\mathrm{C}$, Barberger-Gateau P, Dartigues JF. Ginkgo biloba extract and long-term cognitive decline: a 20-year follow-up population-based study. PLoS One. 2013;8(1):e52755.

25. Brondino N, De Silvestri A, Re S, et al. A systematic review and metaanalysis of Ginkgo biloba in neuropsychiatric disorders: from ancient tradition to modern-day medicine. Evid Based Complement Alternat Med. 2013;2013:915691.

26. Yang G, Wang Y, Sun J, Zhang K, Liu J. Ginkgo biloba for mild cognitive impairment and alzheimer's disease a systematic review and metaanalysis of randomized controlled trials. Curr Top Med Chem. 2016;16(5):520-528

27. Birks J, Grimley Evans J. Ginkgo biloba for cognitive impairment and dementia. Cochrane Database Syst Rev. 2009;(1):CD003120.

28. Oskouei DS, Rikhtegar R, Hashemilar $\mathrm{M}$, et al. The effect of Ginkgo biloba on functional outcome of patients with acute ischemic stroke: a double-blind, placebo-controlled, randomized clinical trial. J Stroke Cerebrovasc Dis. 2013;22(8):e557-e563.

29. Wang L, Zhang T, Bai K. [System evaluation on Ginkgo biloba extract in the treatment of acute cerebral infarction]. Zhong Nan Da Xue Xue Bao Yi Xue Ban. 2015;40(10):10961102. Chinese. 